\title{
AMHTS 受診者の血清遊離グリセロール值
}

$\begin{array}{llllllllll}\text { 加瀬沢 } & \text { 信 } & \text { 彦 } & \text { O村 } & \text { 上 } & \text { 博 } & \text { 美 } & \text { 杉 } & \text { 浦 } & \text { 紀 } \\ \text { 新 里 } & \text { 光 } & \text { 塚 } & \text { 本 } & \text { 博 } & \text { 子 } & \text { 大 } & \text { 高 } & \text { 範 } & \\ \text { 大 畑 } & \text { 泰 子 } & \text { 鈴 } & \text { 木 } & \text { 啓 } & \text { 吾 } & & & & \end{array}$

我々の自動化健診に於て高脂血症の診断が極めて重要 である事から，成人病のスクリーニング検查として，血 清コレステロールと並んでトリグリセライド（TG）の 測定が実施される場合が多い。

現在 TG の測定法は, 日本医師会を始め種々の臨床 検査精度管理調查報告からも明らかに示されている様 に, 酵素的測定法 (GPO) が主流を占めている。しかし ながら,この酵素を用いる測定法の欠点として, 血清 TG を測定する際, 検体に共存する遊離グリセロール （FG）によって正誤差を受け，真の TG 值を与えないと いら問題点が指摘されている。この事を回避するために 種々の方法が試みられているが，一致した見解が未だ得 られていない現状である。この様な事から酵素法を用い た TG 测定に於ける FG 值の取扱いについて検討の余 地があると思われる。

今回, 筆者らは血清 FG 值の存在量とその生理的な 変動に関して, 当センターAMHTS 受診者男子450名を 対象に 4 社 $\mathrm{A}, \mathrm{B}, \mathrm{C}, \mathrm{D}$ の試薬キットを用いて比較 検 討 を行なったので報告する。

〔結果及び考察】1. 化学的測定法であるアセチルア セトン法と GPO 酵素法による 2 試薬系 4 社キットの比 較：4 社いずれの TG 值もアセチルアセトン法と $\mathrm{r}=$ 0.98 と高い相関が得られたが，それぞれの回㷌式には相 違が認められた。

2. 各キット添付標準液（すべてトリオレインを使 用）と測定試薬との組合せによる TG 值の検討：各々 得られた值には表示値との大きな差異が認められ，特に $\mathrm{B}$ 社標準液と $\mathrm{C}$ 社測定試薬との組合せは表示值よりも 28 \%低值を示し, 得られた值の中で際立っていた。標準液 中の安定剂の種類にも起因寸るのではないかと推察され た。

3 . 各社 2 試薬系 TG 測定試薬の吸収曲線 : 検 体 と してグリセロール標準液（トリオレイン $250 \mathrm{mg} / \mathrm{dl}$ に相 当）を使用し，第 1 試薬添加後及び第 2 試薬添加反応後

\section{Serum Free Glycerol concentration of each} subject in AMHTS.

静岡健康管理センター
の吸収を調べた。第 1 試薬添加後, B 社キットでは 730 $\mathrm{nm}$ 付近にピークが見られ，D社キットでは $450 \mathrm{~nm}$ に ピークが認められた。各キット試薬内容に起因するもの と思われ， B社の場合 2 波長測光する場合，第 2 波長の 選択に注意を要する。この様に各社キット毎に吸収曲線 が異なり，測定值に影響を及ぼす原因の一端が考察され た。

4.酵素法に於ける $\mathrm{TG}$ と $\mathrm{FG}$ との関係: 同一試薬 メーカーによる TG と FG のキットを用いて, 両者の 相関を求めたところ， B 社 $\mathrm{r}=0.661 ， \mathrm{D}$ 社 $\mathrm{r}=0.267$ で 2 社キット間に差が認められた。反応系の微妙な相違が 原因であろう。

5. FG 值の度数分布図: D社データは対数正規分布 に近い型を示し，B社データは正規分布に近似してい た。AMHTS 受診者男子に於て $\overline{\mathrm{x}} \pm 2$ S.D. の範囲を算出 すると， D 社では $2 \sim 12 \mathrm{mg} / \mathrm{dl}, \mathrm{B}$ 社では $1 \sim 29 \mathrm{mg} / \mathrm{dl}$ と なり, 平均值では $\mathrm{B}$ 社の方が $\mathrm{D}$ 社のおよそ 3 倍の数值が 得られた。従って, 高值異常の出現する状況も両者で異 なっていることが示された。

6. FG 試薬キット B 社, D 社に於ける相関: 両社 キット間に $\mathrm{r}=0.554, \mathrm{y}=1.52 \mathrm{x}+5.60$ の関係が得られ た。散布図上, 両群から特に離れている高值異常検体に ついて個別に調查したところ, 乳濁及び肝機能異常, 高 血圧, 糖尿病などの出現率が高い検体の多い事が判っ た。また，これらの高值異常例に於ては生活習慣上，多 量飲酒及び常習契煙者が多数を占めていた。

7 . 年齢別, 肥満度 (W/H 比) 別 FG 值 : 加㱓之共 に FG 值が増加する傾向にあり, D 社の FG 值に於て は30代と60代に全年蹂平均值に対して $\mathrm{p}<0.05 て ゙$ 有意な 差が認められた。また，肥満度別に於ける FG 值につ いては有意差は認められなかったが，肥満度増加と共に FG 値の上昇傾向が見られた。

8. 2 試薬系の反応を利用する計測系に於ても, 現状 のキットでは，FG の除去と定量性に関して满足すべき であるとは言難く，また AMHTS 受診者に於て FG 高 值異常例も日常散見されることから，一率に FG 值を 差引く方法にも一考を要すると思われる。 